\title{
AKSES TRANSPORTASI DALAM PENURUNAN BIAYA LOGISTIK KEPULAUAN BERBASIS KOMODITI UNGGULAN LOKAL
}

\author{
Marcus Tukan ${ }^{1, *}$, Hozairi², B.J. Camerling ${ }^{3}$ \\ 1Jurusan Teknik Mesin Fakultas Teknik Universitas Pattimura, Ambon 97233 \\ *Email: marcustukan@gmail.com \\ ${ }^{2}$ Jurusan Teknik Informasi, Fakultas Teknik Universitas Islam Madura, Madura 69351 \\ Email: dr.hozairi@gmail.com \\ 3Jurusan Teknik Mesin Fakultas Teknik Universitas Pattimura, Ambon 97233 \\ Email: camerlingbilly@gmail.com
}

\begin{abstract}
Abstrak. Kelancaran akses kapal dan pelabuhan dapat menurunkan biaya logistik,olehnya itu transportasidipandang sebagai urat nadi perekonomian wilayah. Penurunan biaya logistik (B_L)merupakan fungsi dari kunjungan kapal (Call) dengan kapasitas muatan bongkar yang tersedia $\left(Q_{\text {bongkar }}\right)$, kinerja bongkar $\left(\mathrm{K}_{-} \mathrm{B} / \mathrm{M}\right)$ adalah kemampuan dan efiasiensi penggunaan tenaga kerja bongkar-muat (TKBM) di pelabuhan termasuk peralatan bongkar-muat dipelabuhan pada suatu wilayah, maka efiasiensi biaya logistic transport $\eta \mathrm{B}_{-} \mathrm{L}$ dapat meningkatkan kinerja transporttasi wilayah kepulauan dan kondisi ini akan memberikan dampak turunan terhadap daya beli masyarakat diwilayah kepulaun. Hasil kajian diperoleh parameter $\beta_{0}=-1.102, \beta_{1}=0.001046, \beta_{2}=0.00005, \beta_{4}=$ $+08970, \beta_{4}=0.000000$ dimana kenaikan biaya logistik dapat berpengaruh terhadap Call, Q_bongkar, Kinerja_B/M, PDRB_unggulan, bila $B_{L}$ naik sebesar 1\% akan berdampak juga terhadap semua parameter yang ada. jikakinerja_B/M $=+$ 08970. makaB_L mempunyai korelasi yang cukup baik dengan perbaikan kinerja bongkar barang dipelabuhan dan berpengaruh signifikan terhadap muatan yang berdampak kuat pada penurunan harga dalam mendorong daya beli dan pertumbuhan ekonomi
\end{abstract}

Kata Kunci : logistik, transportasi, biaya.

\begin{abstract}
Smooth access to ships and ports can reduce logistics costs, therefore transportation is seen as the lifeblood of the regional economy. The decrease in logistics $\operatorname{costs}\left(B_{-}\right)$is a function of ship visits (Call) with available loading and unloading capacity ( $Q_{-}$bongkar $)$, unloading performance $\left(K_{-B / M}\right)$ is the ability and efficiency of the use of loading and unloading labor (TKBM) at the port including loading and unloading equipment. loading at a port in an area, the efficiency of logisticBL logistics transport costs can improve the transportation performance of the archipelago and this condition will have a derivative impact on the purchasing power of the people in the islands. The results of the study obtained parameters $0=-1.102,1=0.001046,2=0.00005,4=+$ 08970, $4=0.000000$ where the increase in logistics costs can affect Call, $Q_{-b o n g k a r}$ Performance_B/M, GRDP_unggulan, if $B \_L$ increases by $1 \%$ will have an impact also for all existing parameters. if performance_B/M $=+08970$. then $B_{-} L$ has a fairly good correlation with improved loading and unloading performance at the port and has a significant effect on cargo which has a strong impact on price declines in encouraging purchasing power and economic growth
\end{abstract}

Keywords: logistics, transportation, cost.

\section{PENDAHULUAN}

Senerginya akses transportasi antar moda serta rendahnya biaya logistik menjadi kata kunci dalam menentukan keberhasilan pembangunan ekonomi suatu wilayah, oleh sebab itu transportasi dipandang sebagai urat nadi perekonomian, terutama dalam menggerakan pembangunan yang diikuti dengan upaya 
penurunan biaya logistik antar pulau. Sistem transportasi juga akan berdampak positif jika dimensi sarana transportasi memiliki korelasi positif terhadap ketersediaan potensi ekonomi yang menjadi komoditas unggulan wilayah.

Peningkatan ekonomi suatu wilayah menjadi tujuan dalam upaya meningkatkan kesejahteraan masyarakat. Yang menjadi persoalan saat ini adalah masih tingginya biaya logostik transportasi Indonesia yang mencapai $24 \%$ dari total PDB atau setara dengan lebih kurang Rp 1.820 triliun per tahun (Frost dan Sullivan, 2016). Proporsi besaran biaya logistik ini masih cukup besar dibandingkan Vietnam (20\%), Thailand (15\%), China (14\%), Malaysia, Filipina, dan India (13\%), Taiwan dan Korea Selatan (9\%), serta Singapura dan Jepang (8\%) dimana kondisi ini sebagai dampak geografis Indonesia. Hal ini menjadi kendala dalam upaya pemberdayaan eknomi diwilayah kepulauan.

Dari Permasalahan di atas bahwa tingginya biaya logistik pada suatu wilayah tidak dapat dipisahkan dari peran transportasi, sekaligus merupakan kunci percepatan suksesnya pembangunan berbagai bidang. Olehnya itu penataan transportasi dan logistik perlu dilakukan secara cermat dan tepat. Yang menjadi problem dasar pembangunaan Indonesia sebagai Negara Kepulauan adalah penataan infrastruktur transportasi yang optimal dan efisien [1] wilayah kepulauan.

Sebagai wilayah kepuluan, transportasi memiliki peran penting untuk memicu pemberdayaan ekonomi masyarakat dengan mengedepankan potensi unggulan wilayah. Transportasi antar pulau tidak dapat dipisahkan dengan pelayaran. Pelayaran yang terencana dengan baik merupakan faktor penting dalam penurunan biaya logistik. Revitalisasi konektivitas antar pulau diharapkan dapat mendukung program Tol Laut pemerintah sebagai ikon pembangunan Indonesia dengan menganalisis eksistensi transportasi dan pengaruhnya terhadap biaya logistik. Dengan demikian, kajian akan melihat sejauhmana peran transportasi laut dan pengaruhnya terhadap penurunan biaya logistik. Dengan batasan lingkup permasalahan hanya di pulau Ambon dan Seram sebagai representasi wilayah Kepulauan Maluku dengan mengambil data sekunder yang bersumber dari dinas terkait. Adapun tujuan untuk menganalisis pengaruh transportasi terhadap penurunan biaya logistik wilayah kepulauan.

\section{BAHAN DAN METODE}

\subsection{Transportasi dan Ekonomi}

Transportasi mempunyai pengaruh positif yang kuat terhadap pembangunan dan pertumbuhan ekonomi dan sebaliknya peningkatan produksi barang dan jasa dapat dikaitkan langsung dengan perbaikan transportasi [2]. Sementara [3] mendefenisikan infrastruktur sebagai salah satu faktor penting yang menentukan pembangunan ekonomi.

Lokasi wilayah dan analisa spasial perlu dilakukan dengan memperhatikan factor-faktor utama dan menetukan lokasi pemilihan kegiatan ekonomi, baik pertanian, perikanan, industri, jasa dan lainnya. Secara garis besar terdapat 6 (enam) faktor ekonomi utama yang mempengaruhi lokasi kegiatan ekonomi [4].

The Local and Regional Economic Impacts Of The Port Of Houston [5], dalam studinya dengan menggunakan an economic impact analysis menyimpulkan bahwa aktivitas pelabuhan berdampak pada ekonomi regional dan lokal dengan pertumbuhan pendapatan rata mencapai $10 \%$ pertahun. Implikasi model hubungan transportasi dengan ekonomi dapat dipakai untuk mengukur kemajuan ekonomi wilayah pulau melalui variable infrastruktur, khususnya wilayah maritim atau wilayah pelabuhan [6].

Pengaruh transportasi dalam Perekonomian serta kondisi geografis wilayah secara umum sangat berdampak pada perekonomian masyarakat di wilayah kepulauan Maluku yang cenderung dipengaruhi oleh karakteristik perbedaan karakteristik wilayah kepulauan serta ketersediaan infrastruktur yang dimiliki oleh masing-masing wilayah pulau. Di samping itu, karena transportasi merupakan infrastruktur dasar (basic infrastructure) bagi kegiatan ekonomi, sosial dan budaya [7] maka dalam penelitian ini tidak dapat dilepaskan dari pola kegiatan masyarakat itu sendiri dengan pengaruh tansportasi, dimana pengertian transportasi itu adalah suatu usaha gerakan perindahan baik orang maupun barang dari suatu tempat ke tempat yang lain.

Transportasi juga merupakan kegiatan mengangkut atau usaha untuk memindahkan muatan (barang dan penumpang) dari suatu tempat ke tempat lain, dan sangat vital bagi perekonomian dan pembangunan serta fasilitas penunjang (supporting facility) terhadap pengembangan dan pertumbuhan sektor-sektor lain [8]. Oleh karena itu, kinerja operasional pelayanan transportasi harus ditingkatkan, sehingga efektif dan efisien, dalam melayani 
kebutuhan hidup masyarakat melalui pendekatan terpaduan antarmoda

Untuk itu kondisi ini akan memberikan gambaran pendekatan pola transportasi namun transportasi laut sebagai sarana utama pembangunan ekonomi wilayah perlu dikaji secara komprehensip sehingga dapat memberikan gambaran ilmiah seberapa besar pengaruh transportasi dan sistem logistik dalam perekonomian di Kepulauan Maluku.

Logistik merupakan salah satu kegiatan yang terpusat pada cara untuk mengelola barang melalui tindakan perencanaan dan penentuan kebutuhan, pengadaan, penyimpanan, penyaluran, pemeliharaan dan penghapusan untuk mencapai tujuan yang telah ditetapkan.Logistik juga terkait dengan aktivitas yang fokus untuk mendapatkan produk yang tepat dengan jumlah yang tepat (of the right products) ke tempat yang tepat (to the right place) pada waktu yang tepat (at the right time) pada biaya yang rendah (at the lowest possible cost),[9].Dengan demikian tujuan logistik adalah suatu upaya pengiriman barang jadi dan bermacam-macam material dalam jumlah yang tepat pada waktu yang dibutuhkan, dan dengan total biaya yang terendah [10]. Melalui proses logistikkebutuhan material dari wilayah kepulauan untuk proses produk-produk industry dapat didistribusikan mulai dari produsen sampai ke konsumen (end to end). Seperti terlihat pada Gambar 1 dibawah ini.

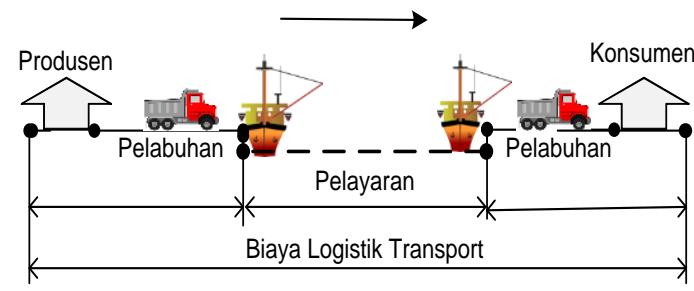

Gambar 1. Diagram model distribusi sistem logistik kepulauan.

Dari gambar tersebut diatas dapat dijelaskan bahwa proses distribusi (produsen sampai ke konsumen) yang mempengaruhi sistem logistik dimulai dari produsen-pelabuhanberangkat pelayaran-pelabuhan tiba-dan akhirnya dikonsumen dimana biaya logistik dalam proses rantai pasok danbiaya produk akhir sangat menentukan harga akhir dari proses distribusi.Dan dalam peneliian ini secara kualitaip ditemukan biaya tinggi yang terjadi di pelabuhan tiba maupun pelabuhan berangkat berada diluar siklus idel sebuah proses logistik sehingga membuat tingginya harga yang diterima konsumen.

\subsection{Transporasi dan Logistik}

Biaya Transportasi, penghitungan biaya logistik tidak lepas dari perhitungan komponen biaya transportasi yang mencakup biaya transportasi untuk memindahkan hasil produk dari pabrik dan pemasok ke gudang (disebut sebagai biaya transportasi sekunder) atau dapat disebut juga sebagai biaya pengiriman produk jadi ke konsumen akhir. Sementara biaya pergerakan barang dari pabrik atau pusat distribusi ke pabrik atau pusat distribusi lain, atau angkutan inbound pembelian barang dari pabrik atau distributor untuk dijual kembali (resale) (disebut sebagai biaya transportasi primer).

Biaya logistik merupakan faktor yang cukup mempengaruhi daya saing suatu wilayah. Dalam mekanisme pasar, biaya logistic juga dapat mempengaruhi hargajual produk akhir. Sementara bagi wilayah pulau, biaya logistik agregat akan memengaruhi pasar ekspor dan impor.

\subsection{Pemodelan Transport dan Biaya Logistik}

Model efisiensi biaya logistik transport dapat digambarkan sebagai berikut:

$\eta B_{-} \_=f\left(\text { Call, } Q \_ \text {muatan, } K_{-} B / M, P D R B \_ \text {Sektoral }\right) . .(1)$

dimana;

$\eta \mathrm{B}_{-} \mathrm{L}=$ effisiensi biaya logistik

$\mathrm{Q} \_$muat $_{\text {- potensi muatan muat }}$

$\mathrm{K} \_\mathrm{B} / \mathrm{M}=$ kinerja tenaga bongkar muat di pelabuhan.

PDRB_sektoral = potensi sectoral unggulan Maluku antara lain sektor perikanan, perkebunan, partanian dan kehutanan.

Gambar diagram 2 adalah model diagram alir hubungan antara kinerja logistic dan transportasi;

Dari gambar diagram 2 dapat dijelaskan bahwa jika biaya logistik (B_L)merupakan fungsi dari kunjungan kapasitas kapal (Call) dengan kapasitas muatan bongkar yang tersedia ( $Q_{\text {bongkar}}$ ), kinerja bongkar (K_B/M) adalah kemampuan dan efiasiensi penggunaan tenaga kerja bongkar-muat di pelabuhan (TKBM) termasuk peralatan bongkarmuat dipelabuhan pada suatu wilayah, maka efiasiensi biaya logistic transport $\eta \mathrm{B} \_$_dapat meningkatkan kinerja transporttasi wilayah kepulauan dan kondisi ini dapat memberikan dampak turunan terhadap daya beli masyarakat diwilayah kepulaun. 


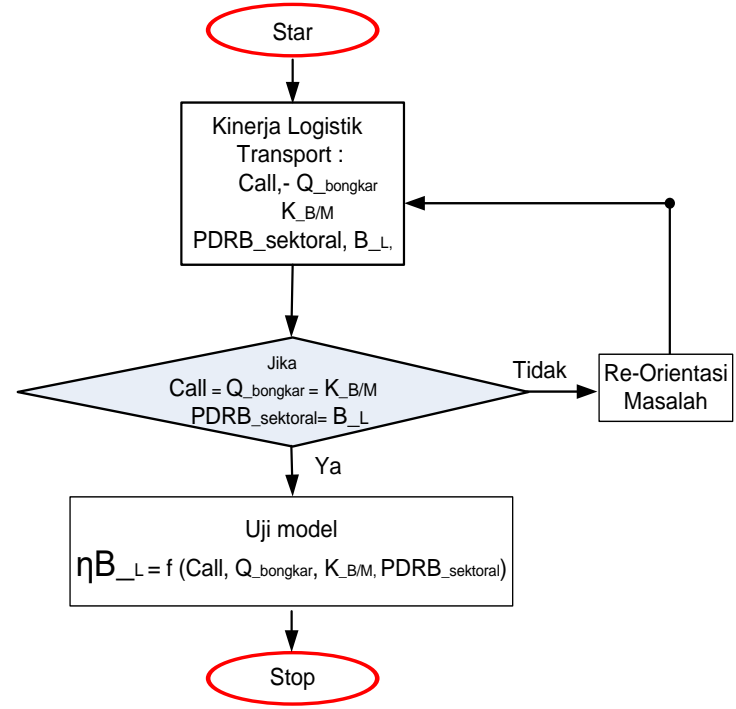

Gambar 2. Diagram alir hubungan transportasi dan biaya logistik.

Uji model data dilakukan dengan melihat hubungan antara load factor kapal (Lf) dengan kinerja logistik, dimana jika $\eta \mathrm{B}_{-} \mathrm{L}=\mathrm{Lf}$ maka secara ekonomi model ini memenuhi syarat keekonomian untuk pengoperasian kapal kargo di wilayah kepulauan.

\subsection{Pemodelan Ekonometrika Dimensi Transportasi dan Biaya Logistik}

Model logistic yang sering disebut sebagai regresi logistik ataumodel logit dalam ilmu statistik, statistika regresi logistik digunakan untuk memprediksi peluang terjadinya suatu peristiwa (probabilitas) dengan menyusun data pada fungsi logit kurva logistik. Seperti analisis regresi umumnya, dimana metode ini menggunakan beberapa variabel prediktor, baik numerik maupun variabel kategori. Metode inimerupakan model linier umum yang digunakan untuk regresi binomial.

Analisis model, dalam mengembangkan model analisis biaya logistik (B_L) yang dilakukan dengan menggunakan teori produksi Cobb Douglass pada persamaan yang melibatkan lebih dari dua variabel, dimana data time series dari kenerja logistic di pelabuhan, seperti jumlah kunjungan kapal (Call) dengan kapasitas muatan bongkar ( $\left.\mathrm{Q}_{\text {bongkar }}\right)$, kinerja bongkar-muat (K_B/M) serta kemampuan dan efiasiensi penggunaan tenaga kerja bongkar-muat di pelabuhan (TKBM) termasuk peralatan bongkar-muat dipelabuhan pada suatu wilayah juga potensi sektoral wilayah sebagai komponen pembentuk PDRB wilayah merupakan input yang diolah dalam bentuk regresi multilinear kemudian dirubah menjadi bentuk Cobb Douglass dimana proses ini merupakan input untuk mencari kondisi maksimum Biaya Logistik yaitu jika biaya logistik transport khususnya di Pelabuhan dapat diturunkan.

\subsection{Data}

Penelitian ini menggunakan data kinerja pelabuhan antara lain : data kunjungan kapal (Call), data muatan bongkar ( $Q_{\text {bongkar }}$ ), kinerja bongkar-muat (K_B/M) serta kemampuan dan efiasiensi penggunaan tenaga kerja bongkar-muat di pelabuhan (TKBM) termasuk peralatan bongkar-muat dipelabuhan pada suatu wilayah dan dilakukan dengan pedekatan kualitatip yang menggunakan skala likert sebagai sebuah skala psikometrik. juga potensi sektoral wilayah sebagai komponen pembentuk PDRB.

Pada penelitian ini didefenisikan bahwa interval penilaian logistic cost antara lain :

Indeks $>40 \%$ : sangat idak baik.. skor 1

Indeks 21\%-39,99\% : kurang baik.. skor 2

Indeks $16 \%-20 \%$ : cukup baik.. skor 3

Indeks 11\%-15,99\% : baik..skor 4

Indeks 5\%-10\% : Sangat baik.. skor 5.

Untuk kinerja bongkar-muat barang yang didukung dengan fasilitas peralatan bongkarmuat dipelabuhan dapat didefenisikan antara lain:

Tidak adanya peralatan B/M..skor 1

Peralatan yang sangat terbatas B/M.. skor 2

Peralatan B/M cukup baik.. skor 3

Peralatan B/M baik.. skor 4

Peralatan B/M Sangat baik.. skor 5.

Tabel 1. Data kunjungan kapal, muatan bongkar, biaya logistik dan pertumbuhan PDRB wilayah pada pelabuhan Ambon.

\begin{tabular}{|c|c|c|c|c|c|}
\hline 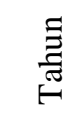 & ల్ & 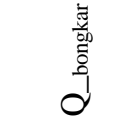 & 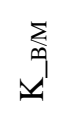 & $\infty^{-1}$ & $\frac{n}{\hat{2}}$ \\
\hline 2013 & 2521 & 68568 & 2 & 1 & 6962687 \\
\hline 2014 & 2775 & 78950 & 3 & 2 & 7909338 \\
\hline 2015 & 2059 & 792499 & 2 & 2 & 8276649 \\
\hline 2016 & 1515 & 861337 & 3 & 3 & 8844786 \\
\hline 2017 & 3461 & 946766 & 4 & 2 & 9491966 \\
\hline
\end{tabular}

Sumber: Maluku Dalam Angka 2018

Hasil survei menunjukan bahwa tren pertumbuhan kunjungan kapal (Call) dari tahun 2013 dimana terjadi peningkatan dan ada penurunan pada tahun 2016 tetapi pada tahun berikutnya terjadilagi peningkatan yang sangat signifikan. Untuk muatan bongkar terjadi peningkatan yang positip sejak tahun 2013 terus meningkat secara dalam kurun waktu lima tahun sampai pada tahun 2017. Sementara kinerja bongkar barang berdasarkan hasil pengamatan dan wawancara lapangan di pelabuhan Ambon 
ditemukan penilaian yang bervariatif terhadap kinerja, tetapi jika dilihat rata-rata menunjukan berada pada kinerja cukup baik. Untuk biaya logistik ditemukan berada pada kinerja kurang baik artinya telah ditemukan masih tingginya biaya logistik dipelabuhan yang terus terjadi dari tahun ke tahun, dimana semua kondisi ini dapat dilihat pada tabel 1 .

\section{HASIL DAN PEMBAHASAN}

Peran transportasi bagi pertumbuhan ekonomi dapat digambarkan sebagai infrastruktur yang memberikan manfaat kepada rumah tangga (household) Perkembangan moda transportasi berkorelasi dengan struktur ekonomi dan mobilitas tenaga kerjadan menyebabkan terjadinya pertumbuhan ekonomi sehingga pada akhirnya memberikan kesejahteraan. Memahami implikasi sosio-ekonomi dari perpindahan atau pergerakan sangat relevan baik dari perspektif bisnis maupun sosial. hal bergantung pada asumsi yang dibuat berdasarkan pengetahuan yang tersedia [11]. Dalam mendorong pembangunan infrastruktur, kontribusi infrastruktur terhadap pembangunan. Keterkaitan antara infrastruktur (sektor transportasi) dengan partumbuhan ekonomi pada konteks pengeluaran pemerintah (goverment spending) disektor transportasi sesuai dengan Teori Keyles (dalam Gardner Ackley, 1961) menyatakan bahwa kegiatan pemerintah merembes ke segala bidang dengan asumsi perekonomian tertutup, dimana $\mathrm{Y}$ adalah pertumbuhan ekonomi $(P D R B)$, Secara sistematis memiliki identitas sebagai berikut: Penelitian tentang efek investasi negara pada infrastruktur (dalam hal ini transportasi dan komunikasi) terhadap pertumbuhan dilakukan oleh Easterly dan Rebelo pada tahun 1993. Dengan menggunakan penilaian variabel sebagai penolong untuk mengindari endogenous yang menghubungkan dua variabel dan kemungkinan hubungan timbal balik sebab akibat. Dengan metode pool regresi, ditemukan bahwa transportasi publik memiliki peran utama menjaga kemajuan pembangunan sehingga transpoortasi perlu dibenahi baik secara kuantitas maupun kualitas.

Yang menjadi kendala pembangunan transportasi di wilayah kepulauan adalah masih tingginya logistic cost dipelabuhan (kurang lebih $70 \%$ ) dari total logistic cost distribusi barang yang ada. Dimana Indonesia saat ini rata-rata biaya logistik mencapai $26,4 \%$ dari produk domestic bruto (PDB).

Gambar 3 di bawah ini dapat dijelaskan bahwa adanya korelasi yang cukup signifikan antara pertumbuhan kinerja muatan bongkar dengan biaya logistic yang terjadi dipelabuhan, dimana peningkatan kinerja mampu menurunkan lgistik cost, tetapi data satu tahun terakhir menunjukan hubungan yang terbalik hal ini menggambarkan bahwa biaya logistik tidak mutlak ditentukan oleh peningkatan muatan bongkar yang terjadi di pelabuhaan.

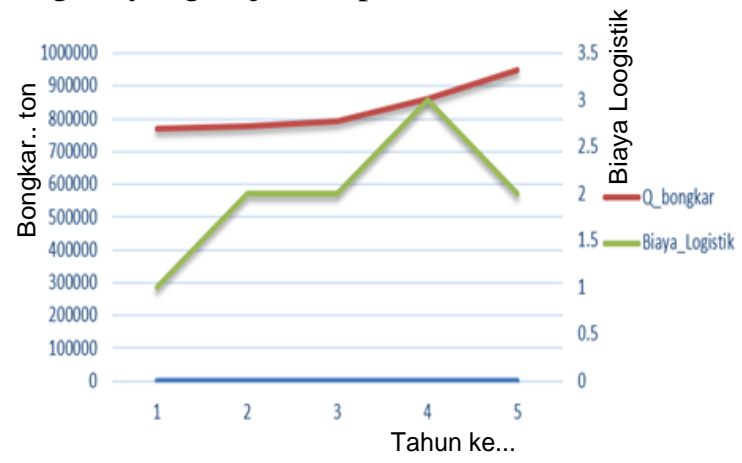

Gambar 3. Diagram hubungan muatan bongkar versus biaya logistik

Gambar 4. di bawah ini dapat dijelaskan bahwa adanya korelasi yang cukup signifikan antara pertumbuhan kinerja muatan bongkar dengan biaya logistic yang terjadi dipelabuhan, dimana peningkatan kinerja mampu menurunkan biaya logistk, tetapi data tahun terakhir menunjukan hubungan yang terbalik dimana biaya logistik justru semakin tinggi sehingga perlu didalami fenomena lain dibalik perubahan ini, seperti yang ditemui saat dilakukan survei lapangan dan ditemukan adanya biaya-biaya nonteknis yang ikut mempengaruhi biaya logistk di pelabuhan.

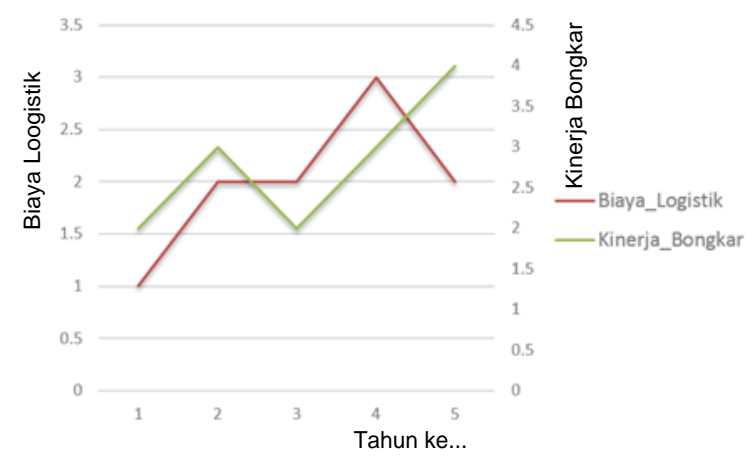

Gambar 4. Diagram hubungan kinerja muatan bongkar versus biaya logistik

Gambar 5 di bawah ini dapat dijelaskan bahwa adanya korelasi yang sangat signifikan antara pertumbuhan muatan bongkar terhadap PDRB dimana pola biaya logistic yang terjadi dipelabuhan pada tahun-tahun pertama sedikit mengalami perbaikannamun pada tahun terakhir 2017 kembali mengalami penurunan Indeks 
kurang baik dengan skor $2(21 \%-39,99 \%)$. Hal ini menunjukan hubungan yang terbalik dimana logistic cost justru semakin tinggi sehingga perlu didalami fenomena lain yang terjadi dipelabuhan dibalik perubahan ini.

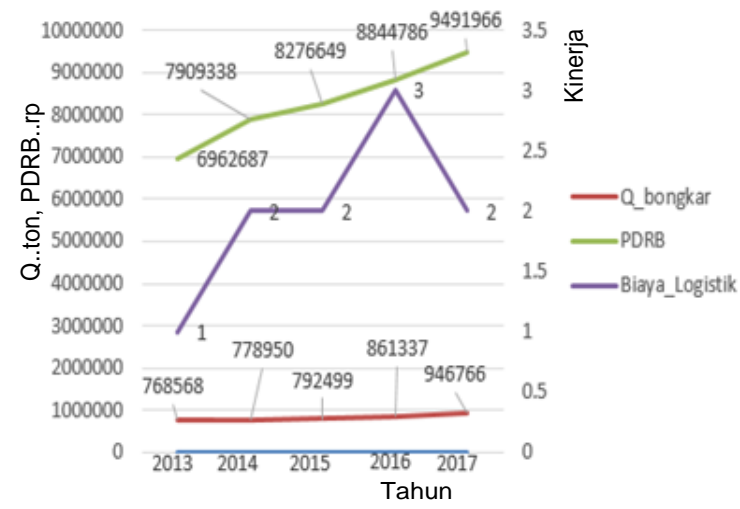

Gambar 5. Diagram hubungan muatan bongkar dan pertumbuhan PDRB terhadap biaya logistik

\subsection{Analisis Logistik Cost Versus Muatan Bongkar}

Hubungan Biaya Logistik(B_L) terhadap pertumbuhan muatan bongkar (Q_bongkar), dan hubungan tersebut dapat dimodelkan dengan ; Regression Analysis: Biaya_LogistikVersus Q_bongkar The regression equation is :

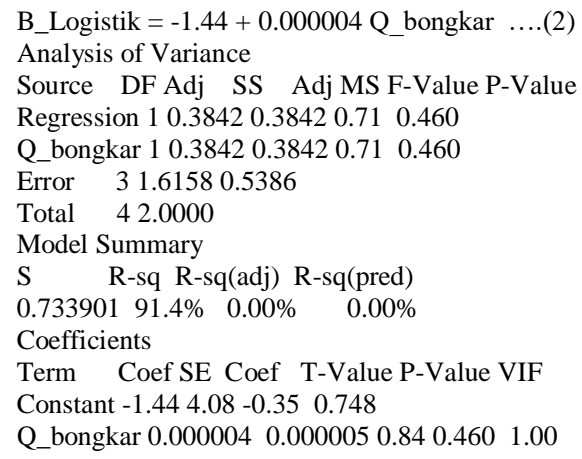

Dari model di atas diketahui parameter $\beta_{0}=$ $1.44, \beta_{1}=0.000004$ artinya pertumbuhan muatan bongkar (Q_bongkar) akan mempengaruhi Biaya Logistic(B_L) dipelabuhan, dimana bila $B_{L}$ naik sebesar $1 \%$ maka Q_bongkar meningkat sebesar $0.000004 \%$.

Dengan nilai $\mathrm{R}^{2}=91.4 \%$, hal ini menunjukan bahwa dari seluruh variasi total $\mathrm{Y}$ yang diterangkan oleh $\mathrm{X}$, sedangkan sisanya $7.6 \%$ factor lain yang tidak diperhitungkan masuk ke model. Sehingga Q_bongkar mempunyai korelasi yang kuat dengan perbaikan logistic cost, walaupun tidak terlalu signifikan akan tetapi memliki pengaruh yang signifikan terhadap muatan yang berdampak kuat terhadap pertumbuhan ekonomi.

\subsection{Analisis Regression Analysis: B_L versus Call, Q_bongkar, Kinerja_B/M, PDRB_unggulan}

Hubungan kinerja Biaya Logistik(B_L) dengan kunjungan kapal (Call) muatanbongkar (Q_bongkar), kinerja bongkar $\mathrm{K} \_$bongkar hubungan tersebut dapat dimodelkan dengan ;

Regression Analysis: Biaya_Logistik versus PDRB_unggulan, Call, Q_bongkar,Kinerja_B Persamaan regresinya adalah :

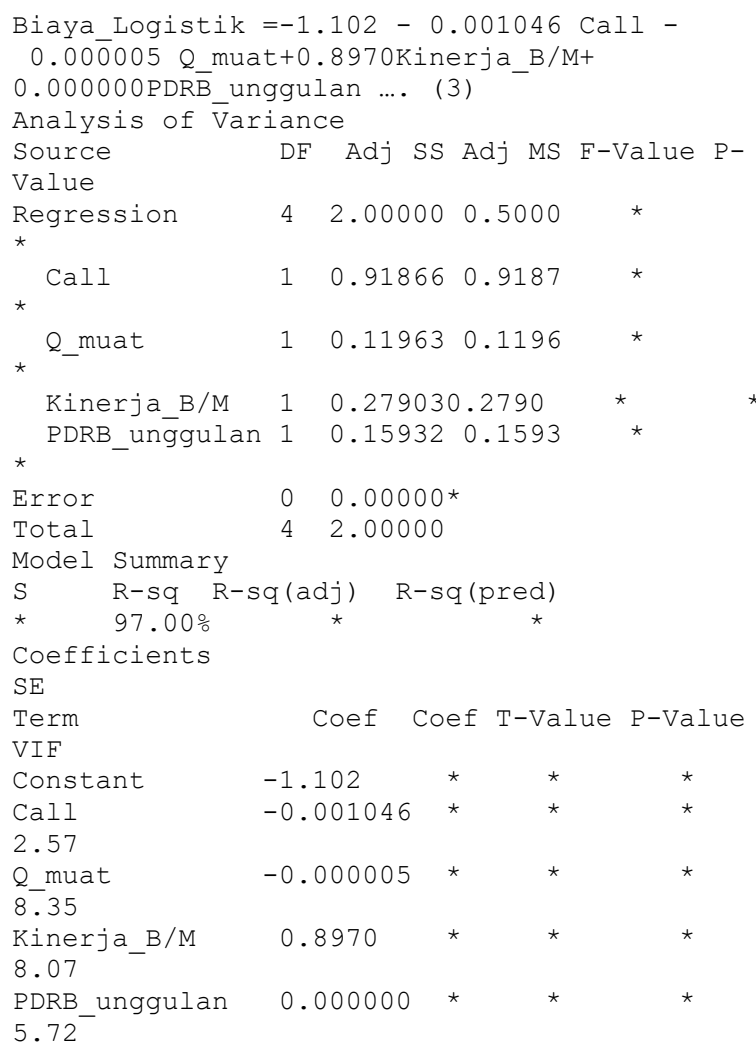

Dari model diatas diketahui parameter $\beta_{0}=-$ $1.102, \beta_{1}=0.001046, \beta_{2}=0.00005, \beta_{3}=+08970$, $\beta_{4}=0.000000$ artinya kenaikan Biaya Logistik dapat berpengaruh teerhadap Call, Q_bongkar, Kinerja_B/M, PDRB_unggulanserta berpengaruh dipelabuhan, dimana bila Logistik_costnaik sebesar $1 \%$ akan berdampak juga terhadap semua parameter yang ada.

Dengan nilai $\mathrm{R}^{2}=97,0 \%$, hal ini menunjukan bahwa dari seluruh variasi total $\mathrm{Y}$ yang diterangkan oleh $\mathrm{X}$, juga menggambarkan adanya korelasi yang kuat dan positip yaitu Kinerja_B/M $=+08970$. Sehingga $B_{-L}$ mempunyai korelasi yang cukup baik dengan perbaikan kinerja bongkar barang dipelabuhan dan berpengaruh signifikan terhadap muatan yang berdampak kuat terhadap penurunan harga dalam mendorong daya beli dan pertumbuhan ekonomi 


\section{KESIMPULAN}

Hasil kajian dan analisis dapat disimpulkan beberapa hal sebagai berikut :

1. Biaya logistik sangat dipengaruhi oleh kinerja muatan bongkar yang ada disuatu pelabuhan wilayah pulau dalam mendukung Tol Laut.

2. Kelancaran volume muatan bongkar memiliki korelasi yang tidak siknifikan dengan terjadinya peningkatan biaya logistik sebab kelancaran bongkar muat tidak berdampak pada biaya.

3. Kenaikan biaya logistik yang terjadi dipalabuhan berada diluar aspek teknis di pelabuhan, karena adanya pihak tertentu yang ikut bermain dalam penetapan tarif muatan bongkar dipelabuhan, hal ini akan memberikan kesan negatif terhadap kinerja pelayaran dan pelabuhan atau terkadang digambarkan sebagai kinerja transportasi yang buruk.

Untuk menurunkan biaya logistik di Pelabuhan perlunya perbaikan manajemen tenaga kerja kontrak dengan tenaga kerja bongkar muat pelabuhan (TKPBM) yang menetapkan tarif bongkar muat sesuai keinginan kelompok, untuk itu dibutuhkan regulasi, pengawasan dan penindakan oleh pemerintah. Dan juga perlunya penelitian lajutan untuk membuktikan model analisis yang digunakan dalam penelitian ini.

\section{DAFTAR PUSTAKA}

[1] Marcus Tukan, (2015), Pelabuhan Berbasis Moodel Ekonomi Kepulauan, Penerbit Unesa University Press, ISBN 978-979-028806-5

[2] Button, K.J., 1982. Transport Economics, Heinemann Educational Books, Ltd., London, pp. 245
[3] Tadaro, Michael P., Economic Development, Seventh Edition, New York, Addition Wesley Longman, Inc, 2000

[4] Sjafrizal, Ekonomi Regional, Teori dan Aplikasi, Baduose Media, Praninta Ofset, Padang Sumatera Barat, 2008

[5] Martin Stopford, Maritime Economics, OX14, Third Edition. P 140.

[6] Marcus Tukan, Pengembangan Pelabuhan Berbasis Model Ekonomi Wilayah Kepulauan Disertai MT093350, ITS, Surabaya, P 130, 2013

[7] Marcus Tukan, Transportasi Kepulauan Dalam Mendukung Tol Laut, Polimedia Publishing, ISBN: 978-602-6372-11-6, pp. 79-80, 90-92, Kampus Polimedia, Jagakarsa Jakarta Selatan 12640, email: polimediapublishing@gmail.com, 2017

[8] Jinca, M. Yamin. 2010. "Keterpaduan SistemJaringan Antar Moda Transportasi di Pulau Sulawesi” Jurnal Transportasi 9(1): [29 November 2016]

[9] Berkowitz, Eric N. Kerin, Roger A. Hartley, S. W., \& Rudelius, W. dalam Budi Sitorus, Tulus Irfan Jurnal Manajemen Transportasi \& Logistik - Vol. 04 No. 02, P137-146, Juli 2017

[10] Bowersox, Donald J. Manajemen Logistik Jilid I. Cetakan Kelima. Bumi Aksara Jakarta 2006

[11] María Alonso Raposo, Monica Grosso, Andromachi Mourtzouchou, Jette Krause, Economic Implications of a Connected and Automated Mobility in Europe, Research in Transportation Economics, journal homepage: www.elsevier.com/locate/retrec $\underline{\text { P6 }}$, April 2021. 